\title{
Apelin and apelin receptor in human placenta: Expression, signalling pathway and regulation of trophoblast JEG-3 and BeWo cells proliferation and cell cycle
}

\author{
EWA MLYCZYŃSKA ${ }^{1}$, PATRYCJA KUROWSKA ${ }^{1}$, ELIZA DRWAL ${ }^{1}$, MAŁGORZATA OPYDO-CHANEK $^{2}$, \\ WACŁAW TWORZYDŁO ${ }^{3}$, MAŁGORZATA KOTULA-BALAK ${ }^{4}$ and AGNIESZKA RAK ${ }^{1}$
}

\begin{abstract}
Departments of ${ }^{1}$ Physiology and Toxicology of Reproduction, ${ }^{2}$ Experimental Haematology, and ${ }^{3}$ Developmental Biology and Invertebrate Morphology, Institute of Zoology and Biomedical Research, Jagiellonian University in Krakow, 30-387Krakow;

${ }^{4}$ University Centre of Veterinary Medicine UJ-UR, University of Agriculture in Krakow, 30-059 Krakow, Poland
\end{abstract}

Received May 7, 2019; Accepted September 10, 2019

DOI: $10.3892 / \mathrm{ijmm} .2020 .4452$

\begin{abstract}
Placentation requires the production of numerous growth factors, hormones and transcription factors. Many of them, like the adipose tissue-derived leptin or adiponectin, have been identified in the placenta and their role has been established in the proliferation and subsequent development of the placenta. Apelin is another adipokine known for proliferative effects in different cell types. PCR, immunoblotting and immunocytochemistry were used to study mRNA and protein expression of apelin and its receptor (APJ) in syncytiotrophoblast (BeWo) and cytotrophoblast (JEG-3) cells as well in immunohistochemistry in human normal placenta slides. The effect of apelin on cell proliferation study was investigated by alamarBlue ${ }^{\circledR}$ and Cell Counting Kit-8 assays, the cell cycle by the flow cytometry method and the protein expression of cyclins and phosphorylation level of extracellular signal-regulated kinases (ERK)1/2, phosphatidylinositol 3'-kinase/protein kinase B (Akt), signal transducer and activator of transcription 3 (Stat3) and 5'-monophosphate-activated protein kinase $(\mathrm{AMPK} \alpha)$ were studied by western blotting. Apelin was increased in JEG-3 compared with in BeWo cells, while APJ was the same in both placenta cell lines. Immunocytochemical analyses revealed high cytoplasmic and/or membrane apelin localisation in JEG-3, while BeWo cells exhibited markedly weaker apelin signal in the cytoplasm. Apelin increased cell proliferation as well as the percentage of cells in the $\mathrm{G} 2 / \mathrm{M}$ phase of the cell cycle, cyclin proteins and the expression of all kinases mentioned above. In conclusion, apelin by
\end{abstract}

Correspondence to: Dr Agnieszka Rak, Department of Physiology and Toxicology of Reproduction, Institute of Zoology and Biomedical Research, Jagiellonian University in Krakow, 9 Gronostajowa Street, 30-387 Krakow, Poland

E-mail: agnieszka.rak@uj.edu.pl

Key words: apelin, proliferation, cell cycle, signal transduction, placenta promotion of trophoblast cell proliferation by APJ and ERK1/2, Stat 3 and AMPK $\alpha$ signalling could be a new important adipokine in the regulation of early placental development.

\section{Introduction}

Placentation is a dynamic and complicated process. After implantation, trophoblasts differentiate into cyto- and syncytio-trophoblast cells, and proliferate much more rapidly than embryo cells, creating an organ in just a few weeks that properly fulfils its function and supports foetus development (1). Any abnormalities in formation and function of the placenta may have serious consequences in foetal life, like intrauterine growth restriction (IUGR) (2), preeclampsia (3), miscarriage (4), as well as long-term complications like cardiovascular (5) and chronic diseases in adulthood (6). Placentation requires the production of growth factors, adhesion proteins, hormones and transcription factors. Numerous factors have been identified in placenta cells and their role has been established in implantation and subsequent development of the placenta $(1,7)$. For example, insulin-like growth factors 1 (IGF1) and IGF2 stimulate cytotrophoblast proliferation and decreased cell apoptosis (8), while leptin promotes trophoblast cell proliferation, survival and invasion (9-11). Moreover, adiponectin has antiproliferative effect in placenta cell lines JEG-3 and BeWo (12).

Apelin is another newly discovered adipokine. In addition to adipose tissue, it is expressed in other tissues like lung, kidney, ovary, heart, brain and blood vessels $(13,14)$. Produced as a 77-amino acid prepropeptide, it is enzymatically cleaved into smaller fragments of 12, 17 and 36 amino acids in length and a 13-amino acid pyroglutamylated peptide that has the strongest physiological effect (15). Of the numerous processes in which apelin is involved, it primarily regulates fluid homeostasis (16), energy metabolism (17), blood pressure (18) and angiogenesis (19). Its actions are mediated by the APJ receptor, a transmembrane receptor associated with a G protein (20). Previous data identified the apelinergic (apelin/apelin receptor APJ) system in cytotrophoblast, syncytiotrophoblast and foetal endothelial cells (3), where it was demonstrated 
that the dominant form in the placental villi is pyr-apelin-13 and apelin-13 (21). In mice, an APJ defect leads to embryo lethality due to significant growth retardation and vascular deformations (22). Studies on rat models showed that in normal pregnancies, the level of apelin in the maternal serum is elevated in the early stages of pregnancy, after which it drops by $50 \%$ in late pregnancy. These changes are caused by the increased clearance of apelin by the gain of activity of the Ang-converting enzyme-related carboxypeptidase-2 (ACE2), which hydrolyses apelin (23). Moreover, during the increase of apelin in the maternal serum, the placenta releases significant amounts of ACE2 (24). Nevertheless, higher foetal apelin concentrations suggest a potential role in foetal growth and ex utero angiogenesis (25). Numerous studies focus on the role of the apelin in the pathophysiology of preeclampsia and in IUGR $(6,21,26)$; however, the action of apelin on trophoblastic cell function, such as proliferation and cell cycle, is still unknown.

Published data led the present study to hypothesise that apelin and APJ can regulate the placenta formation process by action on placental cell proliferation. To verify this hypothesis, two placental cell lines reflecting both syncytiotrophoblast (BeWo) and cytotrophoblast (JEG-3) cells were used. First, the mRNA and protein expression as well as immunolocalisation of the apelinergic system in both cell lines were measured. Moreover, human placenta slides were used to confirm apelin and APJ positive immunolocalisation. Next, the effect of human recombinant apelin-13 on the placental cell proliferation, cell cycle and cyclins D, E, A and B protein expression were analysed. As for the molecular mechanism by which apelin regulates proliferation, the activation of different kinases such as extracellular signal-regulated kinases $1 / 2$ (ERK1/2), phosphatidylinositol 3'-kinase/protein kinase B (Akt), 5'-monophosphate-activated protein kinase $\alpha(\mathrm{AMPK} \alpha)$ and signal transducer and activator of transcription 3 (Stat3) was studied. Kinases PI3K/Akt, ERK1/2, AMPK $\alpha$ and JAK/Stat3 are signalling molecules involved in most types of cell growth, proliferation, survival and apoptosis (27-29) and in the major molecular mechanism of apelin action in other cell types (30-32).

\section{Materials and methods}

Reagents. Phosphate buffered saline (PBS), DMEM/F12 medium and trypsin were purchased from Gibco; Thermo Fisher Scientific, Inc. Insulin, glycerol, EDTA, dithiothreitol, 3,3'-diaminobenzidine (DAB), bromophenol blue, sodium deoxycholate, Nonidet P-40 (NP-40), Tween-20, PD098059, AG490 and apelin-13 (cat. no. A6469) were obtained from Sigma-Aldrich; Merck KGaA. Foetal bovine serum (FBS; heat inactivated) was purchased from Biowest. Tris base, SDS and bovine serum albumin (BSA) were purchased from Bioshop (Canada, Inc.). ML221, LY294002 and Compound C were obtained from Tocris Bioscience, Cell Signaling Technology, Inc. and Merck KGaA, respectively. The WesternBright ${ }^{\mathrm{TM}}$ Sirius kit was purchased from Advansta, Inc. Bradford protein assay kit, 4-20\% gels (cat. no. 456-1093) and membranes (cat. no. 1704156) were obtained from Bio-Rad Laboratories, Inc.

Cell culture and treatment. Syncytiotrophoblast BeWo (cat. no. CCL-98) and cytotrophoblast JEG-3 (cat. no. HTB-36) cell lines were obtained from the American Type Culture Collection. BeWo cells were cultured in DMEM/F12 medium without phenol red, supplemented with $0.01 \mathrm{mg} / \mathrm{ml}$ insulin and 10\% FBS, while JEG-3 cells were cultured in DMEM/F12 medium without phenol red, supplemented only with $10 \%$ FBS. Cell lines were grown in $75-\mathrm{cm}^{2}$ tissue culture flasks in a $37^{\circ} \mathrm{C}$ incubator with a humidified mixture of $5 \% \mathrm{CO}_{2}$ and $95 \%$ air.

Treatment 1 . The aim of this experiment was to analyse mRNA and protein expression of apelin and APJ, as well as immunolocalisation. JEG-3 or BeWo cells $\left(1 \times 10^{4}\right.$ cells/96-well) were cultured in DMEM/F12 with 5\% FBS for $24 \mathrm{~h}$ and then cells were carefully rinsed with PBS and stored in $-70^{\circ} \mathrm{C}$ for mRNA expression analysis, or lysed in ice-cold lysis buffer including $50 \mathrm{mM}$ Tris- $\mathrm{HCl}(\mathrm{pH} \mathrm{7.5)}$ containing $100 \mathrm{mM}$ $\mathrm{NaCl}, 0.5 \%$ sodium deoxycholate, $0.5 \% \mathrm{NP}-40,0.5 \%$ SDS and protease inhibitors and stored at $-20^{\circ} \mathrm{C}$ for protein expression analysis. Immunofluorescence labelling was performed on JEG-3 or BeWo cells, seeding at $2 \times 10^{4}$ cells/4-well labtech (BD Biosciences; Becton, Dickinson and Company) cultured in DMEM/F12 with 5\% FBS for $24 \mathrm{~h}$. Then cells were rinsed with PBS and fixed using absolute methanol for $40 \mathrm{~min}$ at $20^{\circ} \mathrm{C}$.

Treatment 2. In this experiment the effect of human recombinant apelin-13 on cell proliferation and cyclins D, E, A and B protein expression was focused on examine. JEG-3 or BeWo cells $\left(4 \times 10^{3}\right.$ cells/per well of 96 -well plate) were cultured in DMEM/F12 with $10 \%$ FBS for $24 \mathrm{~h}$. Next, media were replaced by DMEM/F12 with $1 \%$ FBS and cells were treated for 24,48 and $72 \mathrm{~h}$ with apelin at doses 0.02, 0.2, 2.0, 20 and $200 \mathrm{ng} / \mathrm{ml}$. The concentrations of apelin were chosen based on the authors' preliminary research and previous study (33). The alamarBlue stock solution or Cell Counting Kit-8 (CCK-8) reagent in amounts equal to $10 \%$ of the incubation volume was added, according to the manufacturers' protocol. BeWo cells $\left(4 \times 10^{3}\right.$ cells/per well of 96 -well plate) were cultured with apelin at doses 2 and $20 \mathrm{ng} / \mathrm{ml}$ for 24,48 and $72 \mathrm{~h}$, then cells were lysed in ice-cold lysis buffer and stored at $-20^{\circ} \mathrm{C}$ for cyclin protein expression analysis.

Treatment 3. The aim of this experiment was to examine the effect of human recombinant apelin-13 on the cell cycle. JEG-3 or BeWo cells $\left(2.5 \times 10^{4}\right.$ cells/per 24-well plate) were cultured in DMEM/F12 with $10 \%$ FBS for $24 \mathrm{~h}$. Then, media were replaced by DMEM/F12 with $1 \%$ FBS and cells were incubated for 24, 48 and $72 \mathrm{~h}$ with $2 \mathrm{ng} / \mathrm{ml}$ of apelin. Both trophoblastic cells were harvested by trypsinisation and washed in PBS. Then, cells were fixed with $70 \%$ cold ethanol at $4^{\circ} \mathrm{C}$ for $60 \mathrm{~min}$ and stored at $-20^{\circ} \mathrm{C}$. These cells were used for measuring the percentage of the total cell population in each phase of the cell cycle.

Treatment 4. The aim of this experiment was to examine the molecular mechanism of the apelin action on BeWo cell proliferation. After $24 \mathrm{~h}$, media were replaced by DMEM/F12 with $1 \% \mathrm{FBS}$ and cells were treated with apelin at $2 \mathrm{ng} / \mathrm{ml}$ for 1, 5, 15, 30, 45, 60 and $90 \mathrm{~min}$. Then, cells were lysed in ice-cold lysis buffer and stored at $-20^{\circ} \mathrm{C}$ for protein expression of kinases phosphorylated p-ERK1/2, total ERK, p-Akt, total Akt, p-Stat3, total-Stat3, p-AMPK $\alpha$ and total AMPK $\alpha$ 
study. To test the activation of kinases in different signalling pathways, cells were pre-treated with selective inhibitors of ERK1/2, Akt, Stat3 and AMPK $\alpha$ kinases (PD98059 at $10 \mu \mathrm{M}$, LY294002 at $10 \mu \mathrm{M}, \mathrm{AG} 490$ at $50 \mu \mathrm{M}$ and Compound $\mathrm{C}$ at $10 \mu \mathrm{M}$, respectively), as well as with the inhibitor of APJ (ML221 at $10 \mu \mathrm{M}$ ) for $1 \mathrm{~h}$, and then apelin at $2 \mathrm{ng} / \mathrm{ml}$ was added. The concentrations of inhibitors were chosen based on the authors' preliminary research and previous study (33). The alamarBlue stock solution was added to the wells in amounts equal to $10 \%$ of the incubation volume to measurement cell proliferation after $72 \mathrm{~h}$ of culture.

Real time PCR. Total RNA isolation and cDNA synthesis (for $1 \mathrm{~h}$ at $37^{\circ} \mathrm{C}$ ) were carried out on cells at the baseline using the TaqMan Gene Expression Cells-to-CT kit (Applied Biosystems; Thermo Fisher Scientific, Inc.), following the manufacturer's protocol. The resulting preamplified cDNA preparations were analysed by quantitative PCR using the StepOnePlus Real-Time PCR System (Applied Biosystems; Thermo Fisher Scientific, Inc.) and TaqMan Gene Expression Assays for apelin (cat. no. Hs00936329_m1; RefSeq NM_017413.4) and APJ (cat. no. Hs00270873_s1; RefSeq NM_005161.4) (Applied Biosystems; Thermo Fisher Scientific, Inc.), in combination with TaqMan Gene Expression Master Mix containing ROX reference dye (Applied Biosystems; Thermo Fisher Scientific, Inc.). The thermal cycling conditions were as follows: $50^{\circ} \mathrm{C}$ for $2 \mathrm{~min}, 95^{\circ} \mathrm{C}$ for $10 \mathrm{~min}$ and then 40 cycles of $95^{\circ} \mathrm{C}$ for $15 \mathrm{sec}$ and $60^{\circ} \mathrm{C}$ for $60 \mathrm{sec}$. Duplicate control samples lacking cDNA were prepared for each gene and showed no DNA contamination. The gene expression was normalized using the geometric mean of three housekeeping genes: GAPDH (cat. no. 4310884E; RefSeq NM_002046.3), TBP (cat. no. Hs00920495_m1; RefSeq NM_001172085.1), YWHAZ (cat. no. Hs01122445_g1; RefSeq NM_001135699.1) the expression of which was stable under these conditions (data not shown). 3T3L1 adipose tissue cells [culture of cells was described (34)] and ovarian follicles cells [isolation and culture of cells were described previously (33)] were used as a positive control to study apelin/APJ expression in the placenta. The normalized values for relative expression $(\mathrm{R})$ were calculated according to the following equation: $\mathrm{R}=\left(\mathrm{E}_{\mathrm{Gene}}{ }^{-\mathrm{Cq} \mathrm{Gene}}\right) /($ geometric mean (EGAPDH ${ }^{-\mathrm{Cq} \text { GAPDH} ; ~} \mathrm{E}_{\mathrm{TBP}}{ }^{-\mathrm{Cq} T \mathrm{TBP}} ; \mathrm{E}_{\mathrm{YWHAZ}^{-\mathrm{Cq}}}{ }^{\text {YWHAZ }}$ ), where $\mathrm{Cq}$ was the cycle threshold and $\mathrm{E}$ was the PCR efficiency for each primer pair (35).

Western blotting. The western blotting procedure used to determine apelin/APJ, cyclins and kinases proteins expression was described previously (33). Briefly, the proteins $(80 \mu \mathrm{g})$ were separated by 4-20\% Mini-Protean TGX System Precast Protein Gels and transferred to Trans-Blot Turbo Mini PVDF Transfer Packs (Bio-Rad Laboratories, Inc.). The membranes were blocked for $1 \mathrm{~h}$ in $0.02 \mathrm{M}$ Tris-buffered saline containing $5 \%$ BSA and $0.1 \%$ Tween-20 at room temperature (RT), then incubated overnight at $4^{\circ} \mathrm{C}$ with appropriate primary antibodies (Table I). The membranes were then washed in Tris-buffered saline containing $0.1 \%$ Tween-20 and incubated for $1 \mathrm{~h}$ at RT with a horseradish peroxidase-conjugated secondary antibody (Table I). $\beta$-actin was used as a loading control. Signals were detected by chemiluminescence using a WesternBright ${ }^{\mathrm{TM}}$ Sirius (cat. no. K-12043-D20; Advansta, Inc.) and visualised using the Chemidoc ${ }^{\mathrm{TM}}$ XRS+ System (Bio-Rad Laboratories, Inc.). All bands were quantified using a densitometer and ImageJ software (version 1.51; US National Institutes of Health).

Immunocytochemistry. After fixation, placenta cells were incubated for 5 min with $0.2 \%$ Triton in PBS. Next, nonspecific binding sites were blocked with $3 \%$ BSA for $3 \mathrm{~h}$ at RT. Thereafter, cells were incubated overnight at $4^{\circ} \mathrm{C}$ in a humidified chamber in the presence of primary antibodies against apelin/APJ (Table I). On the next day, goat anti-mouse antibodies for apelin (cat. no. A11001; Thermo Fisher Scientific, Inc) or goat anti-rabbit antibodies for APJ (cat. no. A10520, Thermo Fisher Scientific, Inc) were applied overnight at $4^{\circ} \mathrm{C}$. After each step, sections were carefully rinsed with PBS. The antibodies were diluted to 1:200 in 3\% BSA.Immunofluorescent staining was protected from light and coverslips were mounted with Fluoroshield mounting medium (Sigma-Aldrich; Merck KGaA) with 4',6-diamidino-2-phenylindole (DAPI) and examined with epifluorescence microscope Leica DMR. To quantitatively evaluate the intensity of immunofluorescent reaction, digital colour images were obtained using a Nikon Coolpix 4500 Video Camera (Nikon Corporation) connected to a video capture card (PV-BT878P1; Prolink Computer, Inc.).

Immunohistochemistry. To optimize immunohistochemical staining, paraffin sections of human placenta tissue slides (GTX24360; GeneTex Inc.) were immersed in $10 \mathrm{mM}$ citrate buffer $(\mathrm{pH} 6.0)$ and heated in a microwave oven $(2 \times 5 \mathrm{~min}$, $700 \mathrm{~W}$ ). Thereafter, sections were immersed sequentially in $3 \% \mathrm{H}_{2} \mathrm{O}_{2}$ for $10 \mathrm{~min}$ at $\mathrm{RT}$ and normal $5 \%$ goat serum (Sigma-Aldrich; Merck KGaA) for $30 \mathrm{~min}$ that were used as blocking solutions. Afterwards, sections were incubated overnight at $4^{\circ} \mathrm{C}$ with primary antibodies against apelin/APJ (Table I). Next, anti-rabbit biotinylated antibody and avidin-biotinylated horseradish peroxidase complex (ABC/HRP; 1:100; Dako; Agilent Technologies, Inc.) were applied at RT in succession. Bound antibody was visualized with $0.05 \%$ DAB as a chromogenic substrate. Control sections included omission of primary antibody and/or substitution by irrelevant IgG. Thereafter, sections were washed and were counterstained with Mayer's hematoxylin at RT for $10 \mathrm{sec}$ and mounted using DPX mounting media (Sigma-Aldrich, Merck KGaA).

AlamarBlue assay. The alamarBlue ${ }^{\circledR}$ assay (cat. no. DAL1100; Invitrogen; Thermo Fisher Scientific, Inc.) is based on quantitation of the cells' metabolic activity and is designed to measure the proliferation of different cell types. Cellular metabolism induces a chemical reduction of the alamarBlue medium, i.e. this assay is based on the quantitative metabolic conversion of the blue, non-fluorescent resazurin to pink, fluorescent resorufin by living cells. AlamarBlue stock solution was aseptically added to the wells in amounts equal to $10 \%$ of the incubation volume as described in a previous study (33). The resazurin reduction was determined after $3 \mathrm{~h}$ incubation with alamarBlue by measuring the absorbance at 570 and $600 \mathrm{~nm}$ wavelengths using a FLUORO reader (BioTek Instruments, Inc.).

Cell Counting Kit-8. Cell Counting Kit-8 (CCK-8; cat. no. 96992; Sigma Aldrich; Merck KGaA) allows sensitive 
Table I. Antibodies used for western blotting and immunofluorescence.

\begin{tabular}{|c|c|c|c|}
\hline Antibody & Host species & Vendor/cat. no. & Dilution \\
\hline Apelin & Mouse & Santa Cruz Biotechnology, Inc./sc-293441 & 1:50 (IHC), 1:200 (WB) \\
\hline APJ & Rabbit & Santa Cruz Biotechnology, Inc./sc-33823 & $1: 100$ (IHC), 1:200 (WB) \\
\hline Cyclin D & Rabbit & $\mathrm{CST} / 2978$ & $1: 1,000(\mathrm{WB})$ \\
\hline Cyclin E & Mouse & Abcam/ab3927 & 1:500 (WB) \\
\hline Cyclin A & Mouse & CST/4656 & $1: 2,000(\mathrm{WB})$ \\
\hline Cyclin B & Rabbit & $\mathrm{CST} / 4138$ & $1: 1,000(\mathrm{WB})$ \\
\hline Phospho-ERK1/2 & Rabbit & CST/9101 & $1: 1,000(\mathrm{WB})$ \\
\hline Total-ERK1/2 & Rabbit & CST/9102 & $1: 1,000(\mathrm{WB})$ \\
\hline Phospho-Akt & Rabbit & CST/9271 & $1: 1,000(\mathrm{WB})$ \\
\hline Total-Akt & Rabbit & CST/9272 & $1: 1,000(\mathrm{WB})$ \\
\hline Phospho-Stat3 & Rabbit & CST/9131 & $1: 1,000(\mathrm{WB})$ \\
\hline Total-Stat3 & Rabbit & CST/4904 & $1: 2,000(\mathrm{WB})$ \\
\hline Phospho-AMPK $\alpha$ & Rabbit & Thermo Fisher Scientific, Inc./PA5-17831 & $1: 1,000(\mathrm{WB})$ \\
\hline Total-AMPK $\alpha$ & Rabbit & Thermo Fisher Scientific, Inc.//PA5-17398 & $1: 1,000(\mathrm{WB})$ \\
\hline$\beta$-actin & Mouse & Sigma-Aldrich; Merck KGaA/A5316 & $1: 3,000(\mathrm{WB})$ \\
\hline Secondary & Anti-rabbit & $\mathrm{CST} / 7074$ & $1: 500$ (IHC), 1:1,000 (WB) \\
\hline Secondary & Anti-mouse & $\mathrm{CST} / 7076$ & 1:500 (IHC), 1:1,000 (WB) \\
\hline
\end{tabular}

CST, Cell Signalling Technology, Inc.; WB, western blotting; IHC, immunofluorescence or immunohistochemistry; ERK, extracellular signal-regulated kinases; Akt, protein kinase B; AMPK $\alpha, 5$ '-monophosphate-activated protein kinase $\alpha$; Stat3, signal transducer and activator of transcription 3 .

colorimetric assays for the determination of cell proliferation. Highly water-soluble tetrazolium salt, CCK-8, is reduced by dehydrogenase activities in cells to give a yellow-coloured formazan dye, which is also soluble in the culture media. The amount of the formazan dye is directly proportional to the number of living cells. After treating cells with apelin, $10 \mu \mathrm{l}$ CCK- 8 solution was added and the plate was further incubated for $4 \mathrm{~h}$. Then, the absorbance at $450 \mathrm{~nm}$ wavelength was measured using an ELISA reader (BioTek Instruments, Inc.).

Flow cytometry. Before staining with propidium iodide (PI), the cells were washed twice in $1 \mathrm{ml}$ of PBS, then the cell pellet was resuspended in $300 \mu$ of the PI/RNase staining buffer (BD Biosciences; Becton, Dickinson and Company) and incubated for $30 \mathrm{~min}$ in the dark at RT. The red fluorescence of PI was measured by FACSCalibur flow cytometer (Becton, Dickinson and Company). A total of 10,000 cells were examined per sample. The percentage of cell population in each cell cycle phase (G0/G1, S and G2/M) was calculated from DNA content histograms using the WinMDI 2.8 Software (The Scripps Research Institute).

Statistical analysis. All experimental data were expressed as the mean \pm standard error of the mean of three independent experiments $(n=3)$. Distribution of normality was checked by Shapiro-Wilk test. A one-way or two-way analysis of variance, followed by Tukey's test (GraphPad Prism 5 Software, Inc.), was used to determine any difference between treatments with apelin and control. $\mathrm{P}<0.05$ was considered to indicate a statistically significant difference.

\section{Results}

Expression of apelin/APJ in human trophoblastic cells. The expression (mRNA and protein) of apelin and its receptor, APJ, were studied in cytotrophoblast JEG-3 and syncytiotrophoblast BeWo cells to compare their expression in both cell lines. Using quantitative PCR, it was demonstrated that mRNA expression of apelin was 5-fold higher in JEG-3 compared with BeWo cells (5.518 vs. 0.002, respectively), while mRNA expression of APJ was at the same level in both placental cells $(\mathrm{P}<0.05$; Fig. 1A). Additionally, the present study observed that in JEG-3 cells, apelin expression was increased compared with APJ, while in BeWo cells, APJ expression was higher than apelin. Immunoblotting results confirmed these data $(\mathrm{P}<0.05$; Fig. 1B). Immunocytochemical analyses revealed a strong cytoplasmic signal for apelin in JEG-3 cells. On the other hand, BeWo cells exhibited a weak punctuate signal for apelin in the cell cytoplasm. A moderate immunosignal for APJ was revealed in the cell cytoplasm of both placental cell lines. Occasionally in BeWo cells, a strong signal was located in the perinuclear area (Fig. 1C).

To confirm the results from immunocytochemical studies in the cell lines apelin/APJ expression was analysed in the human placenta slides. It was observed that both apelin and the presence of APJ was revealed, however the signal intensity was dependent on the type of placental cell/structure. In detail, a strong signal for apelin was visible in the cytoplasm of endothelial lining of blood capillaries (Fig. 2A) and in the maternal blood (Fig. 2B and C), while cells of the placental artery exhibited a moderate intensity of the apelin signal (Fig. 2E). A moderate to weak signal intensity for APJ was 

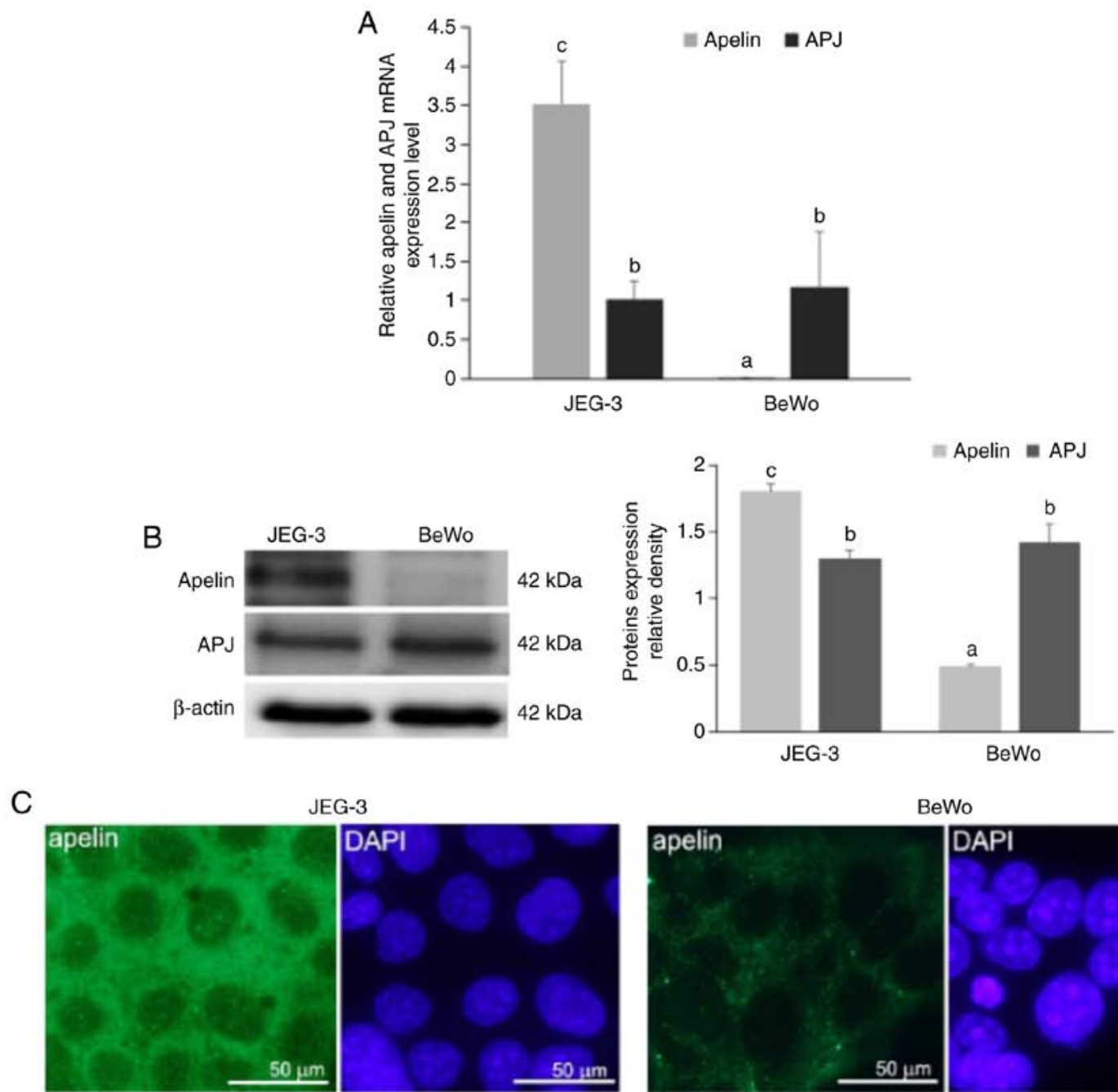

JEG-3
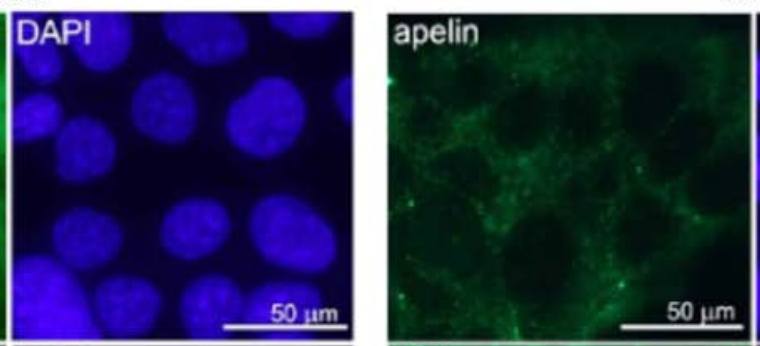

BeWo
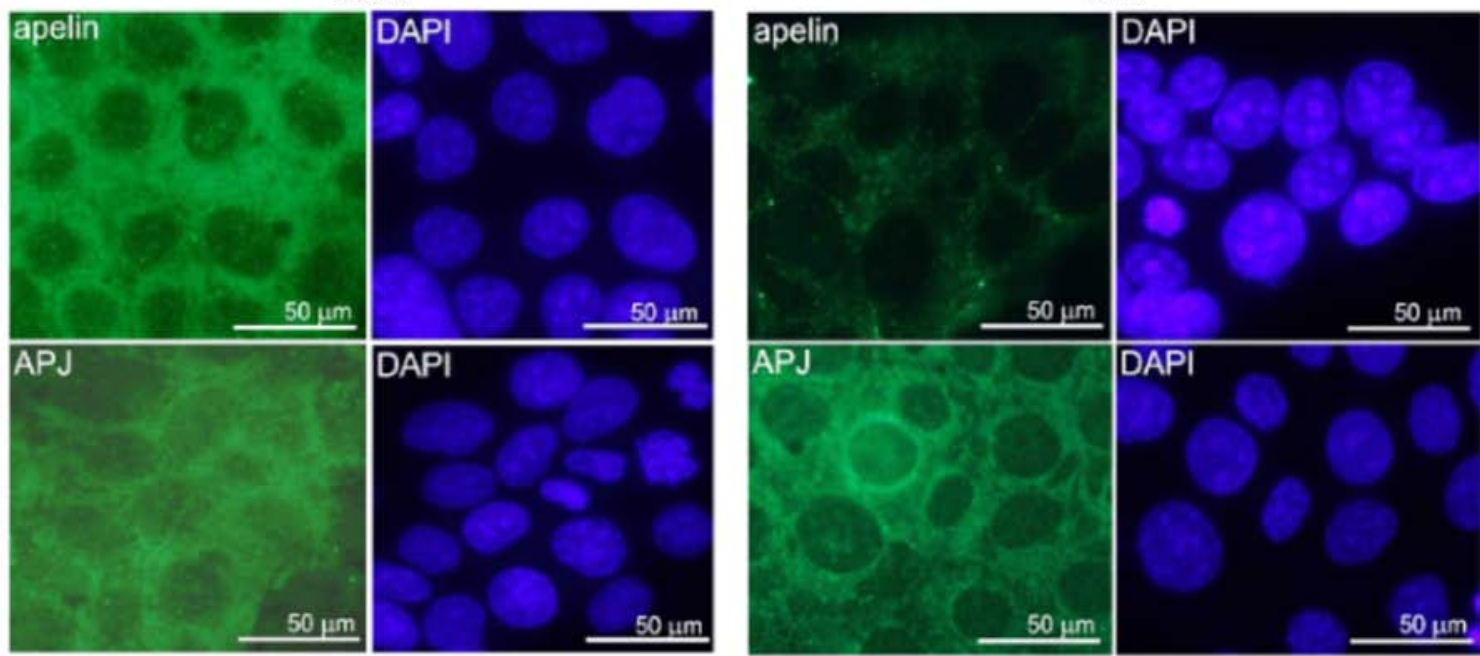

Figure 1. Expression and immunolocalisation of apelin and APJ in JEG-3 and BeWo cells. (A) mRNA (B) protein expression (C) immunofluorescence labelling. Different letters indicate significant differences at $\mathrm{P}<0.05$ between both cell lines and apelin/APJ expression. DAPI, 4',6-diamidino-2-phenylindole.

demonstrated in the cytoplasm of epithelial cells of vesicles and mesenchymal cells of the Whartons jelly (Fig. 2F), but only a few cells of the placental artery exhibited signal (Fig. 2G). A strong signal for APJ was seen in cells of the syncytiotrophoblast (Fig. 2H). No positive signals were found when tissues were incubated with omission of primary antibodies (Fig. 2D and I).

Dose- and time-dependent effect of apelin on trophoblastic cell proliferation. Based on the results showing higher expression of apelin in the cytotrophoblast, which represent the proliferative population inside placental villi, it was decided to study the direct role of apelin on human placenta cells proliferation. The present study showed that in JEG-3 cells, apelin significantly increased cell proliferation after $24 \mathrm{~h}$ at $0.02,0.2$,
2.0 and $20 \mathrm{ng} / \mathrm{ml}$ doses, after $48 \mathrm{~h}$ at 0.2 and $2.0 \mathrm{ng} / \mathrm{ml}$ doses and after $72 \mathrm{~h}$ at $0.02 \mathrm{ng} / \mathrm{ml}$ dose $(\mathrm{P}<0.05, \mathrm{P}<0.01$ and $\mathrm{P}<0.001$, respectively; Fig. 3A). In BeWo cells, it was also observed that apelin increased cell proliferation after $24 \mathrm{~h}$ at $0.02,0.2$ and $2.0 \mathrm{ng} / \mathrm{ml}$ doses, after $48 \mathrm{~h}$ at $0.2,2.0$ and $20 \mathrm{ng} / \mathrm{ml}$ doses and after $72 \mathrm{~h}$ at 2.0 and $20 \mathrm{ng} / \mathrm{ml}$ doses $(\mathrm{P}<0.05, \mathrm{P}<0.05$ and $\mathrm{P}<0.001$, respectively; Fig. 3B).

To confirm the current findings, a CCK- 8 assay was used as a second method to measure cell proliferation. The present study showed that in JEG-3 during 24 and $48 \mathrm{~h}$ incubation, apelin at 0.2 and $2.0 \mathrm{ng} / \mathrm{ml}$ and during $72 \mathrm{~h}$ at $2 \mathrm{ng} / \mathrm{ml}$ had a significant stimulatory effect on cell proliferation $(\mathrm{P}<0.05$; Fig. 3C), while in BeWo, after 24 and $48 \mathrm{~h}$ at $0.2 \mathrm{ng} / \mathrm{ml}$ and after 48 and $72 \mathrm{~h}$ at $2.0 \mathrm{ng} / \mathrm{ml}$ of apelin, cell proliferation was increased ( $\mathrm{P}<0.01$; Fig. 3D). 


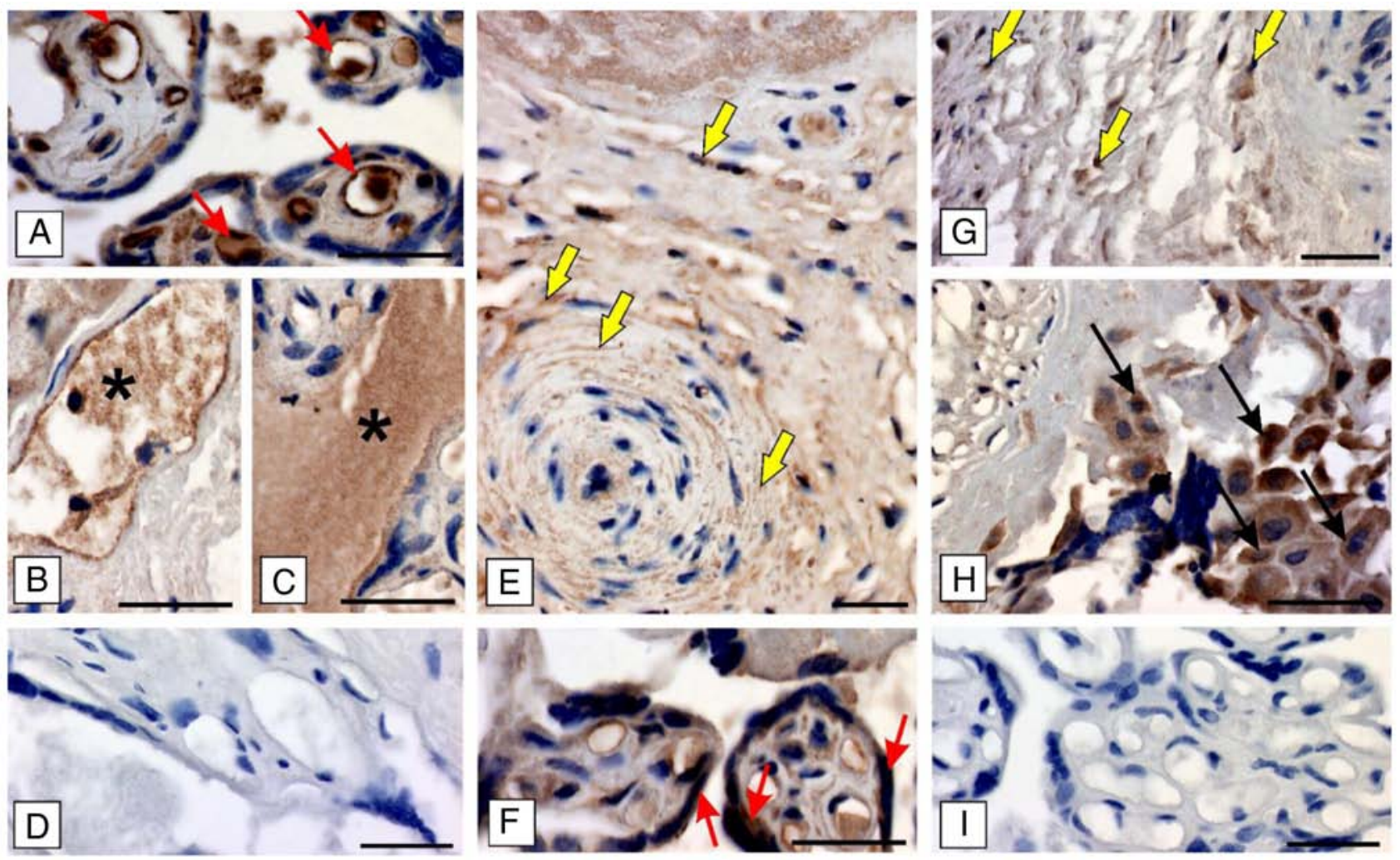

Figure 2. Immunolocalisation of apelin in human placenta tissue. Localisation of the apelin in endothelial lining of blood capillaries (red arrows; A), maternal blood (asterisks; B and C), placental artery (yellow arrows; E) and APJ in epithelial cells of vesicles and mesenchymal cells of the Whartons jelly (red arrows; F), in a few cells of the placental artery (yellow arrows; G), syncytiotrophoblast (black arrows, H). Immunohistochemistry was performed on normal human placenta slides. No positive signals were found when tissues were incubated without the primary antibodies (D and I).
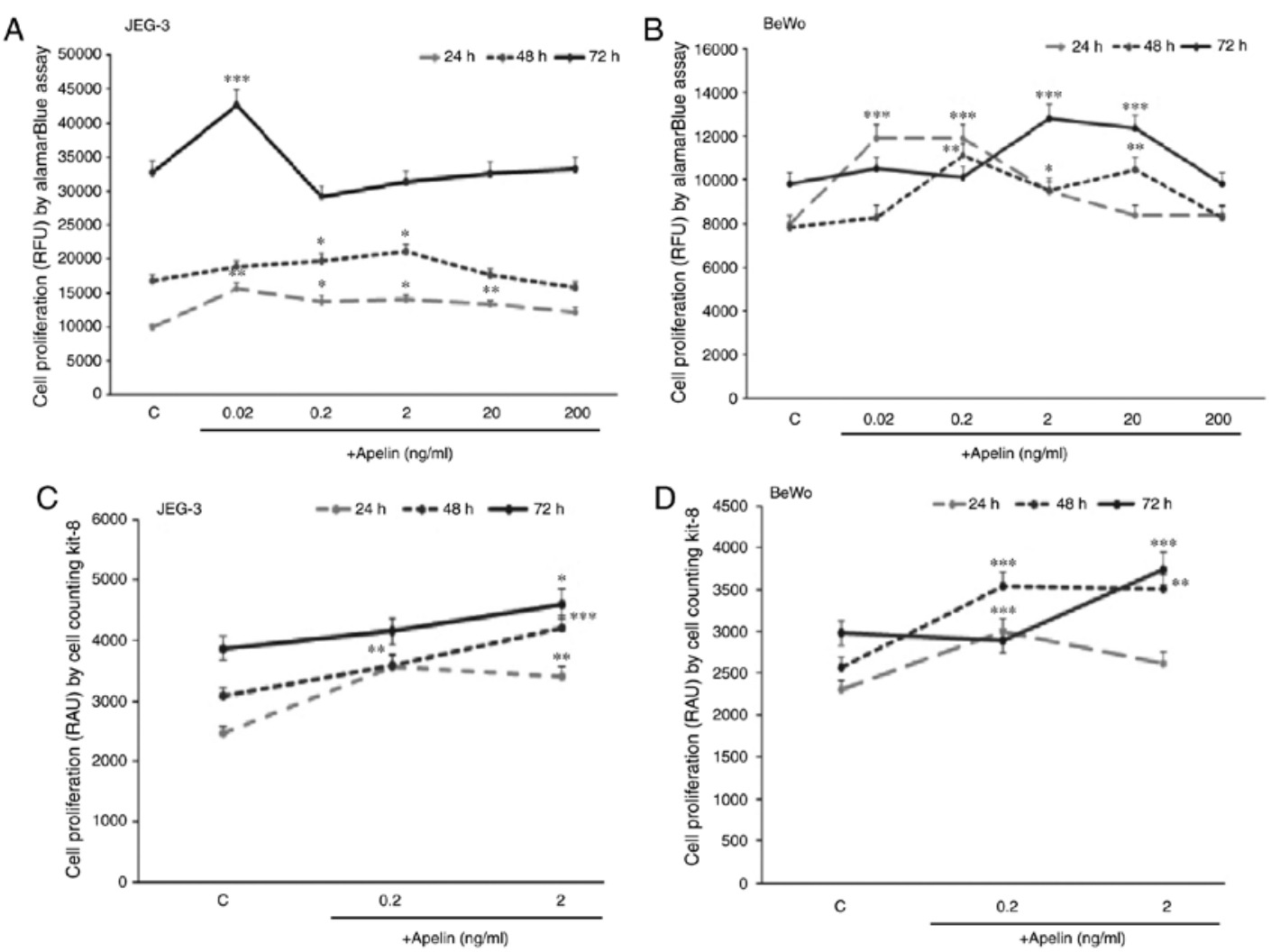

Figure 3. Dose- and time-dependent effect of recombinant human apelin-13 on JEG-3 and BeWo cell proliferation. Cell proliferation was measurement by (A) Alamar Blue in JEG-3 and (B) BeWo cells and (C) Cell Counting Kit-8 in JEG-3 and in (D) BeWo cells. The results are expressed as the mean \pm standard error of the mean of three independent cultures. Statistical analysis was carried out using one-way analysis of variance, followed by Tukey's test. " $\mathrm{P}<0.05$, ${ }^{* *} \mathrm{P}<0.01$ and ${ }^{* * *} \mathrm{P}<0.001$ vs. the control within the same time of incubation. RFU, relative fluorescent unit. 

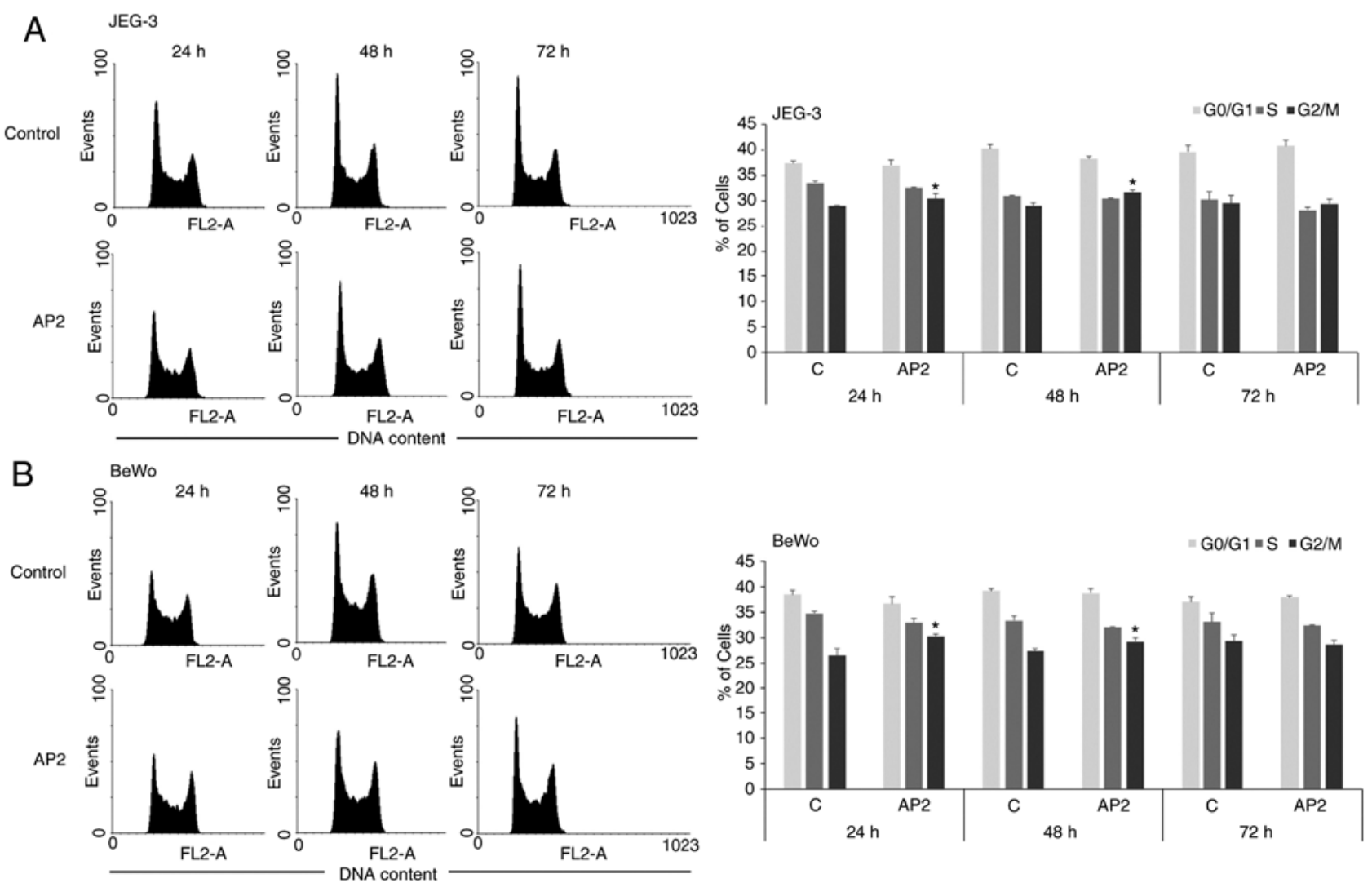

Figure 4. Effect of recombinant human apelin-13 on JEG-3 and BeWo cell cycle. Representative histograms of the cell cycle and the percentage of propidium iodide stained (A) JEG-3 and (B) BeWo cells in the particular phases of cell cycle. The results are expressed as the mean \pm standard error of the mean of three independent cultures. Statistical analysis was carried out using one-way analysis of variance, followed by Tukey's test. "P<0.05 vs. G2/M phase of the corresponding control.

Effect of apelin on the cell cycle in human trophoblastic cells. To further confirm the influence of apelin on placental cell proliferation, the action of apelin on cell cycle distribution was investigated. In both trophoblastic JEG-3 and BeWo cells it was observed that apelin at dose $2.0 \mathrm{ng} / \mathrm{ml}$ significantly increased the percentage of cells in $\mathrm{G} 2 / \mathrm{M}$ phase of cell cycle after 24 and $48 \mathrm{~h}$ of incubation ( $\mathrm{P}<0.05$; Fig. 4).

Effect of apelin on protein expression of cyclins in human trophoblastic BeWo cells. It is well established that cyclins function as regulators of proliferation-related cell cycle progression. Therefore, in the present study, the effect of apelin on protein expression of cyclins D, E, A and B in human trophoblastic BeWo cells was studied. Apelin at both doses, 0.2 and 2.0 $\mathrm{ng} / \mathrm{ml}$ significantly increased cyclin $\mathrm{D}$ protein expression after 48 and $72 \mathrm{~h}$ incubation $\left({ }^{*} \mathrm{P}<0.05\right.$ and ${ }^{* *} \mathrm{P}<0.01$; Fig. 5A and B). It was also observed that apelin increased cyclins $\mathrm{E}, \mathrm{A}$ and $\mathrm{B}$ protein expression after $72 \mathrm{~h}$ of cell incubation at 0.2 and $2.0 \mathrm{ng} / \mathrm{ml}$ for cyclin E, and $2.0 \mathrm{ng} / \mathrm{ml}$ for cyclins A and B $\left({ }^{*} \mathrm{P}<0.05\right.$ and $^{* *} \mathrm{P}<0.01$; Fig. 5A and B). Analysis of cyclins blots showed that cyclin $\mathrm{E}$ can be detected as a doublet of $50 \mathrm{kDa}$ and a single band of $42 \mathrm{kDa}$, as described in datasheet of producer antibodies (Abcam). Moreover, in cyclin B a molecular weight shift was observed among bands, suggesting the possibility of posttranslational modification in the proteins.

Molecular mechanism of apelin action on human trophoblastic BeWo cell proliferation. Apelin is known to activate various signalling pathways in different cell types (31-33). Therefore, the effect of apelin $(2.0 \mathrm{ng} / \mathrm{ml})$ on ERK1/2, PI3K/Akt, JAK/Stat 3 and AMPK $\alpha$ was investigated over different incubation periods. These pathways were focused on as they have previously been shown to be involved in regulation of cell proliferation (28-30). Apelin has a stimulatory effect on the phosphorylation of kinase p 42 of ERK1/2 after $30 \mathrm{~min}$, Akt after $1 \mathrm{~min}$ and Stat 3 after 1,5 and $45 \mathrm{~min}$ of incubation $(\mathrm{P}<0.05$; Fig. $6 \mathrm{~A}$ and $\mathrm{B})$. Moreover, AMPK $\alpha$ activation was increased from 1 to $45 \mathrm{~min}$ and 90 min of incubation with apelin. Kinase inhibitors PD098059, AG490 and Compound C as well as ML221 resulted in a reversal of apelin-stimulated cell proliferation to control levels, except inhibitor LY294002 (Fig. 6C).

\section{Discussion}

Apelin is a pleiotropic peptide, but its major action relates to energy metabolism, cardiovascular function, body fluid homeostasis and the last study also documented female reproduction. Previously published studies indicate that apelin is involved in pregnancy by i) regulation of blood pressure and angiogenesis in the preeclampsia pathophysiology; ii) effects on plasma volume expansion in foetal growth; and iii) regulation of glucose metabolism in the gestational diabetes pathophysiology $(21,23,25)$. However, there are no data regarding the direct effects of apelin in trophoblast cell proliferation or the cell cycle. In the present study, the expression 

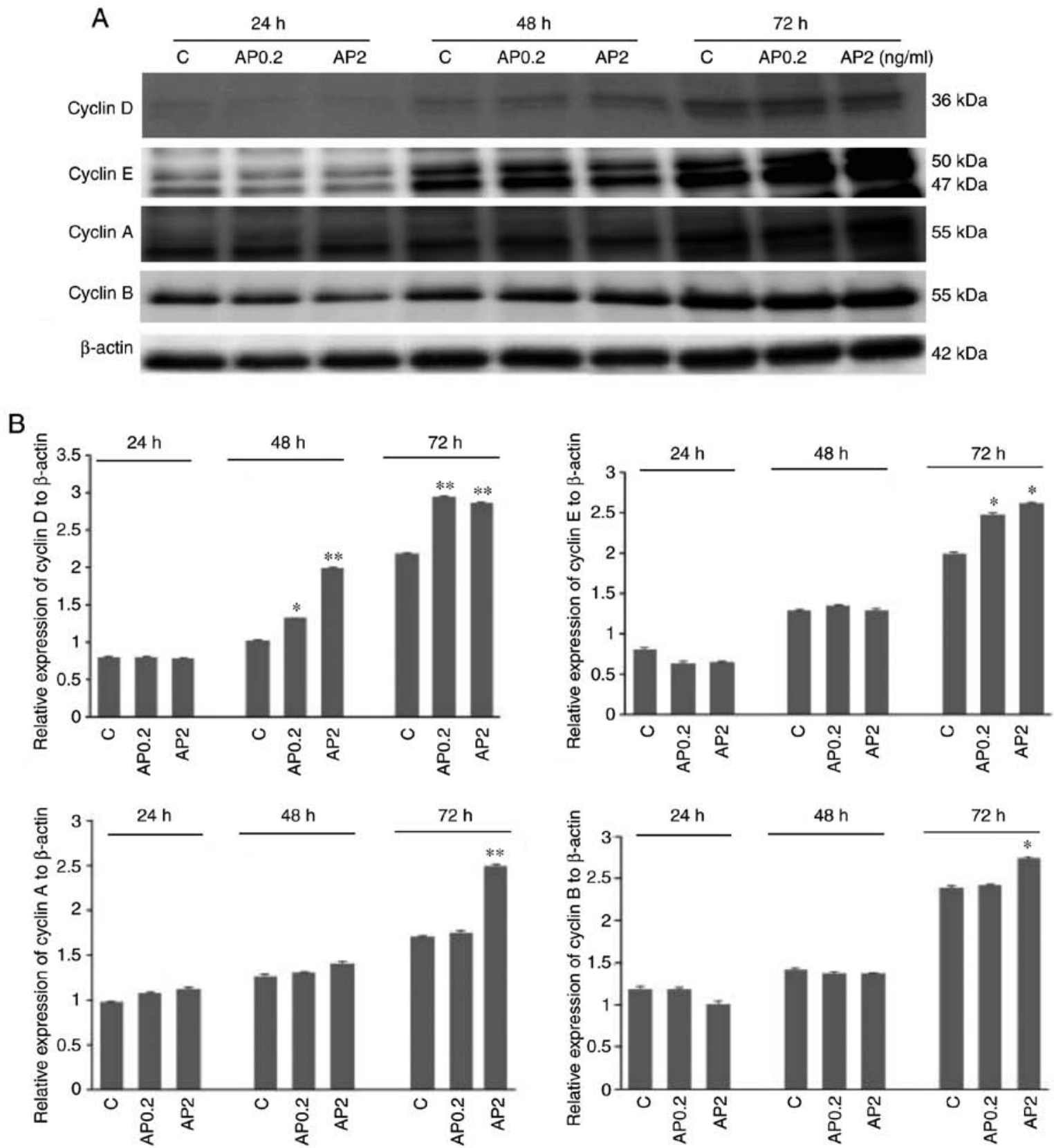

Figure 5. Effect of recombinant human apelin-13 on cyclins protein expression by (A) western blotting and (B) densitometry analysis. The results are expressed as the mean \pm standard error of the mean of three independent cultures. Statistical analysis was carried out using one-way analysis of variance, followed by Tukey's test. ${ }^{*} \mathrm{P}<0.05,{ }^{* *} \mathrm{P}<0.01$ vs. the control within the same time of incubation.

and immunolocalization of the apelinergic system was first checked in both human trophoblastic cell lines syncytiotrophoblast BeWo and cytotrophoblast JEG-3 as well as in human placenta slides. Both these cells lines maintained numerous characteristics of human trophoblastic cells and have been widely used to study cellular and molecular signalling in the placenta (36-38). Additionally, the molecular mechanism involved in the human recombinant apelin-13 action on cell proliferation was investigated.

The results of the present study clearly demonstrated that apelin expression was higher in cytotrophoblast JEG-3 cells than syncytiotrophoblast BeWo cells, while APJ was at the same level in both placental cell lines. Moreover, in JEG-3 cells, apelin expression was increased compared with
APJ, while in BeWo cells, higher expression of APJ than apelin was noted. These results agree with previous data by Cobellis et al (3), showing that the level of apelin expression in the human placenta was much higher in cytotrophoblast cells compared to syncytiotrophoblast. Cytotrophoblast are mononucleated cells that represent the proliferative population inside placental villi; this particular localization suggests the direct role of apelin/APJ on human placenta cells proliferation. Additionally, high cytoplasmic and/or membrane apelin localisation was also described in JEG-3 cells, while BeWo cells exhibited weaker apelin signal in the cell cytoplasm. Immunolocalization of APJ revealed a moderate signal in the cell cytoplasm in both placental cells, while a weaker signal was observed within the nuclei. Additionally, 
A
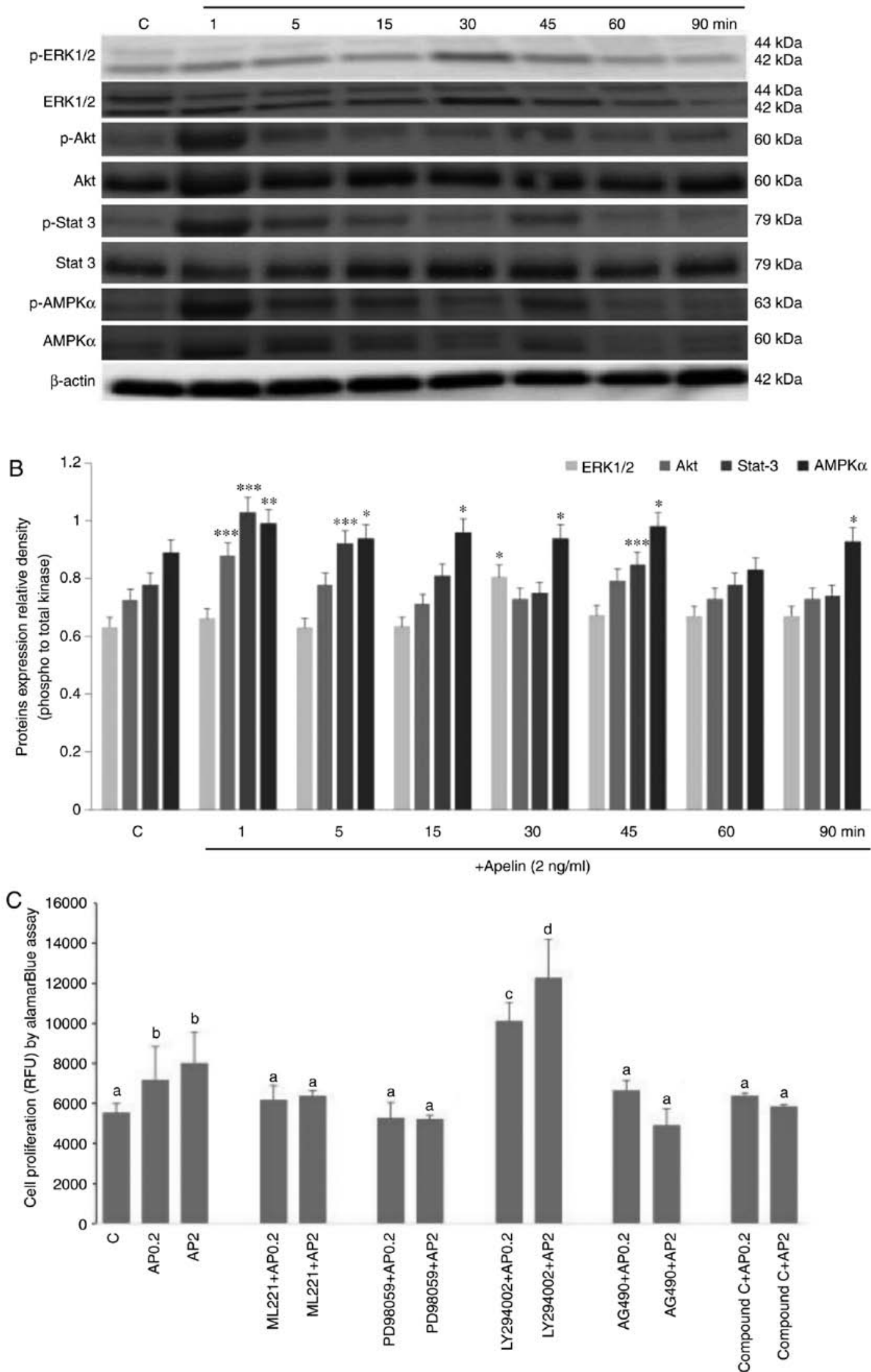

Figure 6. Molecular mechanism of mitogenic action of apelin-13. Kinases p-ERK1/2, total ERK, p-Akt, total Akt, p-Stat3, total-Stat3, p-AMPK $\alpha$ and total AMPK $\alpha$ were detected by (A) western blotting and (B) densitometry analysis. Cells were pre-treated for $1 \mathrm{~h}$ with selective inhibitors of ERK 1/2, Akt, Stat3 and AMPK $\alpha$ kinases (PD98059, LY294002 and AG490 Compound C respectively) and APJ inhibitor (ML221), after which apelin (2 ng/ml) was added for $72 \mathrm{~h}$ and cell proliferation was studied (C). The results are expressed as the mean \pm standard error of the mean of three independent cultures. Statistical analysis was carried out using one-way analysis of variance ${ }^{*} \mathrm{P}<0.05,{ }^{* * *} \mathrm{P}<0.01,{ }^{* * * *} \mathrm{P}<0.001$ vs. the control or two-way analysis of variance, followed by Tukey's test. Different letters indicate significant differences at $\mathrm{P}<0.05$. RFU, relative fluorescent unit; $\mathrm{p}$, phosphorylated; ERK, extracellular signal regulated kinase; Akt, protein kinase B; Stat3, signal transducer and activator of transcription 3; AMPK $\alpha, 5$ '-monophosphate-activated protein kinase $\alpha$. 
immunohistochemistry on human placental slides showed a strong signal for apelin in the cytoplasm of the endothelial lining of blood capillaries and in maternal blood, while cells of the placental artery exhibited a moderate intensity of the apelin signal. A moderate to weak signal intensity for APJ was located in the cytoplasm of epithelial cells of vesicles and mesenchymal cells of the Whartons jelly and a strong signal for APJ was observed in cells of the syncytiotrophoblast. The results of the present study demonstrating expression of apelin/APJ in endothelial and epithelial cells of vesicles were confirmed by a previous study documenting apelin expression in the vascular endothelial cells lining blood vessels of the human heart, rat blood vessels and a high level in endothelial cells of other vessels (39). In the light of these observations Cobellis et al (3) presented the hypothesis that apelin expressed by endothelial cells, acting on vascular smooth muscle in a paracrine fashion has a vasoconstrictor potential and can be a biochemical marker in preeclampsia, which is characterized by endothelial dysfunction. The current results partly confirmed this hypothesis. To summarize the first part of the present study, the expression of both components (ligand and receptor) of the apelin signalling system provides the opportunity for analysis of the direct role of apelin in human placenta cells.

Since the cytotrophoblast cells represent the proliferative population inside placental villi, this particular localisation led the present study to investigate a possible role for apelin in the regulation of proliferation, as previously demonstrated on other models like gastric epithelial cells (40) or umbilical endothelial cells (41). The present study observed that apelin increased placental cell proliferation. This effect was observed with human recombinant apelin-13 concentrations ranging from 0.02 to $20 \mathrm{ng} / \mathrm{ml}$, whereas the literature data documented that apelin is significantly decreased in pregnant women (4.45-8.7 $\mathrm{ng} / \mathrm{ml}$ vs. $5.0-9.3 \mathrm{ng} / \mathrm{ml}$ in control) (42). In the present study, apelin-13 was used because data presented by Yamaleyeva et al (21) documented that apelin-13,(Pyr1)-apelin and possibly oxidised apelin-12 were the major forms in both normal and preeclamptic chorionic villi. In fact, apelin has been shown to exhibit mitogenic action in numerous cell types, including cardiomyoblast cells (43), ovarian cells (33), vascular smooth muscle cells (VSMC) (44) and endothelial cells (45).

Cell cycle analysis was performed to determine the mechanisms underlying the proliferative effects of apelin on placenta cells. The present data indicate the important role of apelin in placenta cell cycle progression. Apelin stimulates the transition to $\mathrm{G} 2 / \mathrm{M}$ phase that is required for cell division and, as shown by further analysis, cyclins were involved in the observed apelin effect. Therefore, modulation of the cell cycle and expression of cyclins by apelin is strictly connected with its biological activity. It is well known that progression through the G2/M is connected with the expression of cyclin B, among other proteins. An enhancement of cyclins D, E, A and B in response to human recombinant apelin-13 was found. Cyclins and cyclin-dependent kinases are subunits of cell cycle-dependent protein kinases that regulate key events during the progression of the cell cycle (46). Moreover, the level of cyclin proteins is selectively expressed in different phases of the cell cycle, for example the rise in cyclin D is followed later during G1 by the appearance of cyclin E, which rapidly disappears towards the beginning of DNA synthesis (S phase) (47). Mitogenic signals (e.g., growth factors and serum compounds) that stimulate cell progress through G1 coincide with an increased expression of cyclin D. The present study found enhancement of cyclin D expression in response to apelin at the 48 time point. Therefore, earlier modulation of cyclin D by apelin facilitated cell cycle progression. It is known that after progression through the cyclin D-dependent portion of the cell cycle, cyclin E becomes activated (48) and further facilitates cell cycle progression through $\mathrm{S}$ towards $\mathrm{G} 2 / \mathrm{M}$ phase. Current results strongly indicate that apelin modulates cell cycle progression by affecting the activation of cyclins, especially cyclin D and E. Cyclin A begins to appear towards the end of G1, continues to rise during the $S$ phase and then through $\mathrm{G} 2$ phase rapidly declines as the cell progresses, while level of cyclin $\mathrm{B}$ begins to appear during the $\mathrm{S}$ phase. This rise continues into the G2 phase before rapidly falling during the mitotic phase (47). Therefore, apelin can enhance the cell cycle by promoting the switch of cells from $\mathrm{S}$ phase to G2/M phase. Additionally, it is a well-known fact that the increase in expression of the cell cycle machinery is a key event in regulating cell proliferation. Further studies are needed to understand how apelin cooperates with precise signalling pathways to regulate these cyclins. The present results agree with data of Li et al (44) indicating that apelin increased cell cycle progress by stimulating the expression of cyclins D1 and E in VSMC cells.

The last part of the current study focused on description of the molecular mechanism of apelin action in placenta cells by studying the effect of apelin on signalling pathways and next the role of APJ receptor and activation of different kinases was investigated. The present study showed that apelin at $2 \mathrm{ng} / \mathrm{ml}$ stimulated phosphorylation of kinases ERK1/2, Akt, Stat3 and AMPK $\alpha$, but cell proliferation was reduced to control levels in the culture with pharmacological inhibitors of APJ receptor and kinases ERK1/2, Stat 3 and AMPK $\alpha$ but not Akt. In the authors' preliminary studies all inhibitors of kinases ERK1/2, Akt, Stat3 and AMPK $\alpha$ (PD98059 at $10 \mu \mathrm{M}, \mathrm{LY} 294002$ at $10 \mu \mathrm{M}, \mathrm{AG} 490$ at $50 \mu \mathrm{M}$ and Compound $\mathrm{C}$ at $10 \mu \mathrm{M}$, respectively), as well as inhibitor of APJ (ML221 at $10 \mu \mathrm{M}$ ) were used alone to check that their concentration and no effect on cell proliferation was observed. Previous data showed that apelin induced cell proliferation by activation of different signalling pathways through PI3/Akt activation in rat granulosa cells (49), endothelial progenitor cells (50) and retinal pigment epithelial cells (30); or via ERK1/2 in human breast cancer cells (MCF-7) (51) and lung adenocarcinoma (52). These observations suggest that the molecular mechanism of the mitogenic action of apelin is cell specific. Thus, a potentially new mechanism of apelin action can be described as follows: Apelin-induced stimulation of trophoblastic cell proliferation regulates early placental development. As a result, the condition of the placenta directly indicates the well-being of the developing foetus.

In conclusion, the results of the present study noted that apelin is produced by trophoblastic cells and can be involved in the human placenta physiology. It was observed that this adipokine by stimulation of placenta cell proliferation via APJ activation and kinases ERK1/2, Stat 3 and AMPK $\alpha$ pathways can be new regulator of early placental development. The limitations of the study must also be acknowledged. All in vitro results were obtained using human placenta cell lines, so the structure and local microenvironment in the placenta tissue did not exist. To complete these results, future studies on 
placenta explants or in vivo animals models will be necessary for understanding the role of apelin on placenta cells physiology. For example, Van Mieghem et al (23) conducting the apelin studies on rats documented that maternal plasma apelin levels decreased in the last week of gestation due to increased elimination by the fetoplacental unit, however role of apelin on animal placenta models are still unknown.

\section{Acknowledgements}

Not applicable.

\section{Funding}

The present study was supported by the Jagiellonian University (grant no. K/ZDS/008063). The cost of Open Access publication was covered by the Society for Biology of Reproduction in Poland.

\section{Availability of data and materials}

The datasets used and/or analyzed during the present study are available from the corresponding author upon reasonable request.

\section{Authors' contributions}

EM and AR designed the study. EM, PK, ED, MOC, WT and MKB performed the experiements. EM, MOC and MKB analysed the data. EM and AR prepared the manuscript. All authors have seen and approved the final published version of this manuscript.

\section{Ethics approval and consent to participate}

Not applicable.

\section{Patient consent for publication}

Not applicable.

\section{Competing interests}

The authors declare that they have no competing interests.

\section{References}

1. Maltepe E, Bakardjiev AI and Fisher SJ: The placenta: Transcriptional, epigenetic, and physiological integration during development. J Clin Invest 120: 1016-1025, 2010.

2. Scifres CM and Nelson DM: Intrauterine growth restriction, human placental development and trophoblast cell death. J Physiol 587: 3453-3458, 2009.

3. Cobellis L, De Falco M, Mastrogiacomo A, Giraldi D, Dattilo D, Scaffa C, Colacurci N and De Luca A: Modulation of apelin and APJ receptor in normal and preeclampsia-complicated placentas. Histol Histopathol 22: 1-8, 2007.

4. Reus AD, El-Harbachi H, Rousian M, Willemsen SP, SteegersTheunissen RP, Steegers EA and Exalto N: Early first-trimester trophoblast volume in pregnancies that result in live birth or miscarriage. Ultrasound Obstet Gynecol 42: 577-584, 2013.

5. Murphy VE, Smith R, Giles WB and Clifton VL: Endocrine regulation of human fetal growth: The role of the mother, placenta, and fetus. Endocr Rev 27: 141-169, 2006.
6. Briana DD and Malamitsi-Puchner A: Intrauterine growth restriction and adult disease: The role of adipocytokines. Eur J Endocrinol 160: 337-347, 2009.

7. Knöfler M and Pollheimer J: IFPA Award in Placentology lecture: Molecular regulation of human trophoblast invasion. Placenta 33 (Suppl): S55-S62, 2012.

8. Forbes K, Westwood M, Baker PN and Aplin JD: Insulin-like growth factor I and II regulate the life cycle of trophoblast in the developing human placenta. Am J Physiol Cell Physiol 294: C1313-C1322, 2008.

9. Caüzac M, Czuba D, Girard J and Hauguel-de Mouzon S: Transduction of leptin growth signals in placental cells is independent of JAK-STAT activation. Placenta 24: 378-384, 2003.

10. Schulz LC and Widmaier EP: The effect of leptin on mouse trophoblast cell invasion. Biol Reprod 71: 1963-1967, 2004.

11. Magariños MP, Sánchez-Margalet V, Kotler M, Calvo JC and Varone CL: Leptin promotes cell proliferation and survival of trophoblastic cells. Biol Reprod 76: 203-210, 2007.

12. Benaitreau D, Dieudonné MN, Dos Santos E, Leneveu MC, Mazancourt Pd and Pecquery R: Antiproliferative effects of adiponectin on human trophoblastic cell lines JEG-3 and BeWo. Biol Reprod 80: 1107-1114, 2009.

13. De Falco M, De Luca L, Onori N, Cavallotti I, Artigiano F, Esposito V, De Luca B, Laforgia V, Groeger AM and De Luca A: Apelin expression in normal human tissues. In Vivo 16: 333-336, 2002.

14. Kurowska P, Barbe A, Różycka M, Chmielińska J, Dupont J and Rak A: Apelin in reproductive physiology and pathology of different species: A critical review. Int J Endocrinol 2018: 9170480, 2018.

15. Boucher J,Masri B, DaviaudD, Gesta S, Guigné C, Mazzucotelli A, Castan-Laurell I, Tack I, Knibiehler B, Carpéné C, et al: Apelin, a newly identified adipokine up-regulated by insulin and obesity. Endocrinology 146: 1764-1771, 2005.

16. Lee DK, Cheng R, Nguyen T, Fan T, Kariyawasam AP, Liu Y, Osmond DH, George SR and O'Dowd BF: Characterization of apelin, the ligand for the APJ receptor. J Neurochem 74: 34-41, 2000.

17. Bertrand C, Valet $P$ and Castan-Laurell I: Apelin and energy metabolism. Front Physiol 6: 115, 2015.

18. Tatemoto K, Takayama K, Zou MX, Kumaki I, Zhang W, Kumano K and Fujimiya M: The novel peptide apelin lowers blood pressure via a nitric oxide-dependent mechanism. Regul Pept 99: 87-92, 2001.

19. Kidoya $\mathrm{H}$ and Takakura $\mathrm{N}$ : Biology of the apelin-APJ axis in vascular formation. J Biochem 152: 125-131, 2012.

20. Tatemoto K, Hosoya M, Habata Y, Fujii R, Kakegawa T, Zou MX, Kawamata Y, Fukusumi S, Hinuma S, Kitada C, et al: Isolation and characterization of a novel endogenous peptide ligand for the human APJ receptor. Biochem Biophys Res Commun 251: 471-476, 1998.

21. Yamaleyeva LM, Chappell MC, Brosnihan KB, Anton L, Caudell DL, Shi S, McGee C, Pirro N, Gallagher PE, Taylor RN, et al: Downregulation of apelin in the human placental chorionic villi from preeclamptic pregnancies. Am J Physiol Endocrinol Metab 309: E852-E860, 2015.

22. Charo DN, Ho M, Fajardo G, Kawana M, Kundu RK, Sheikh AY, Finsterbach TP, Leeper NJ, Ernst KV, Chen MM, et al: Endogenous regulation of cardiovascular function by apelin-APJ. Am J Physiol Heart Circ Physiol 297: H1904-H1913, 2009.

23. Van Mieghem T, van Bree R, Van Herck E, Pijnenbor R, Deprest J and Verhaeghe J: Maternal apelin physiology during rat pregnancy: The role of the placenta. Placenta 31: 725-730, 2010.

24. Hanssens A, Marx-Deseure S, Lecoutre L, Butruille A, Fournel C, Knauf C, Besengez C, Breton L, Storme P, Deruelle, et al: Maternal obesity alters the apelinergic system at the feto-maternal interface. Placenta 39: 41-44, 2016.

25. Malamitsi-Puchner A, Gourgiotis D, Boutsikou M, Baka S, Hassiakos D and Briana DD: Circulating apelin concentrations in mother/infant pairs at term. Acta Paediatr 96: 1751-1754, 2007.

26. Van Mieghem T, Doherty A, Baczyk D, Drewlo S, Baud D, Carvalho J and Kingdom J: Apelin in normal pregnancy and pregnancies complicated by placental insufficiency. Reprod Sci 23: 1037-1043, 2016.

27. Cheng JQ, Lindsley CW, Cheng GZ, Yang H and Nicosia SV: The Akt/PKB pathway: Molecular target for cancer drug discovery. Oncogene 24: 7482-7492, 2005.

28. Thompson $\mathrm{N}$ and Lyons $\mathrm{J}$ : Recent progress in targeting the Raf/MEK/ERK pathway with inhibitors in cancer drug discovery. Curr Opin Pharmacol 5: 350-356, 2005. 
29. Pereira de Sousa FL, Chaiwangyen W, Morales-Prieto DM, Ospina-Prieto S, Weber M, Photini SM, Sass N, Daher S, Schleussner E and Markert UR: Involvement of STAT1 in proliferation and invasiveness of trophoblastic cells. Reprod Biol 17: 218-224, 2017.

30. Qin D, Zheng XX and Jiang YR: Apelin-13 induces proliferation, migration, and collagen I mRNA expression in human RPE cells via PI3K/Akt and MEK/Erk signaling pathways. Mol Vis 19: 2227-2236, 2013

31. Li Y, Bai YJ, Jiang YR, Yu WZ, Shi X, Chen L, Feng J and Sun GB: Apelin-13 is an early promoter of cytoskeleton and tight junction in diabetic macular edema via PI-3K/Akt and MAPK/Erk and MAPK/Erk signaling pathways. Biomed Res Int 2018: 3242574, 2018.

32. Różycka M, Kurowska P, Grzesiak M, Kotula-Balak M, Tworzydło W, Rame C, Gregoraszczuk E, Dupont J and Rak A: Apelin and apelin receptor at different stages of corpus luteum development and effect of apelin on progesterone secretion and $3 \beta$-hydroxysteroid dehydrogenase ( $3 \beta$-HSD) in pigs. Anim Reprod Sci 92: 251-260, 2018.

33. Rak A, Drwal E, Rame C, Knapczyk-Stwora K, Słomczyńska M Dupont $J$ and Gregoraszczuk EL: Expression of apelin and apelin receptor (APJ) in porcine ovarian follicles and in vitro effect of apelin on steroidogenesis and proliferation through APJ activation and different signaling pathway. Theriogenology 96 : 126-135, 2017

34. Jasaszwili M, Wojciechowicz T, Billert M, Strowski MZ, Nowak KW and Skrzypski M: Effects of adropin on proliferation and differentiation of 3T3-L1 cells and rat primary preadipocytes. Mol Cell Endocrinol 496: 110532, 2019.

35. Livak KJ and Schmittgen TD: Analysis of relative gene expression data using real-time quantitative PCR and the 2(-Delta Delta C(T)) method. Methods 25: 402-408, 2001

36. Rebut-Bonneton C, Segond N, Demignon J, Porquet D and Evain-Brion D: Effects of calcitonin on human trophoblastic cells in culture: absence of autocrine control. Mol Cell Endocrinol 85: 65-71, 1992.

37. Zygmunt M, Hahn D, Munstedt $\mathrm{K}$, Bischof $\mathrm{P}$ and Lang $\mathrm{U}$ : Invasion of cytotrophoblastic JEG-3 cells is stimulated by hCG in vitro. Placenta 19: 587-593, 1998

38. Standley PR and Standley CA: Identification of a functional $\mathrm{Na}+/ \mathrm{Mg} 2+$ exchanger in human trophoblast cells. Am J Hypertens 15: 565-570, 2002.

39. Wysocka MB, Pietraszek-Gremplewicz K and Nowak D: The role of apelin in cardiovascular diseases, obesity and cancer. Front Physiol 9: 557, 2018.

40. Wang G, Anini Y, Wei W, Qi X, OCarroll AM, Mochizuki T, Wang HQ, Hellmich MR, Englander EW and Greeley GH Jr: Apelin, a new enteric peptide, localization in the gastrointestinal tract, ontogeny, stimulation of gastric cell proliferation and of cholecystokinin secretion. Endocrinology 145: 1342-1348, 2004.
41. Masri B,Knibiehler B and Audigier Y: Apelin signaling: A promising pathway from cloning to pharmacology. Cell Signal 17: 415-426, 2005.

42. Kourtis A,Gkiomisi A,Mouzaki M,Makedou K, Anastasilakis AD, Toulis KA, Gerou S, Gavana E and Agorastos T: Apelin levels in normal pregnancy. Clin Endocrinol (Oxf) 75: 367-371, 2011

43. Yin L, Zhang P, Li C, Si J, Wang Y, Zhang X, Zhang D, Zhang H and Lin C: Apelin-13 promotes cell proliferation in the H9c2 cardiomyoblast cell line by triggering extracellular signal-regulated kinase $1 / 2$ and protein kinase B phosphorylation. Mol Med Rep 17: 447-451, 2018.

44. Li F, Li L, Qin X, Pan W, Feng F, Chen F, Zhu B, Liao D, Tanowitz H, Albanese $\mathrm{C}$ and Chen L: Apelin-induced vascular smooth muscle cell proliferation: The regulation of cyclin D1. Front Biosci 13: 3786-3792, 2008.

45. Sorli SC, van den Berghe L, Masri B, Knibiehler B and Audigier Y: Therapeutic potential of interfering with apelin signalling. Drug Discov Today 11: 1100-1106, 2006.

46. Sánchez I and Dynlacht BD: New insights into cyclins, CDKs, and cell cycle control. Semin Cell Dev Biol 16: 311-321, 2005

47. Bertoli C, Skotheim JM and de Bruin RA: Control of cell cycle transcription during G1 and S phases. Nat Rev Mol Cell Biol 14: 518-528, 2013.

48. Foster DA, Yellen P, Xu L and Saqcena M: Regulation of G1 cell cycle progression: Distinguishing the restriction point from a nutrient-sensing cell growth checkpoint(s). Genes Cancer 11: $1124-1131,2010$.

49. Shuang L, Jidong W, Hongjuan P and Zhenwei Y: Effects of apelin on proliferation and apoptosis in rat ovarian granulosa cells. Clin Exp Obstet Gynecol 43: 409-413, 2016.

50. Zhang J, Liu Q, Hu X, Fang Z, Huang F, Tang L and Zhou S: Apelin/APJ signaling promotes hypoxia-induced proliferation of endothelial progenitor cells via phosphoinositide-3 kinase/Akt signaling. Mol Med Rep 12: 3829-3834, 2015.

51. Peng X, Li F, Wang P, Jia S, Sun L and Huo H: Apelin-13 induces MCF-7 cell proliferation and invasion via phosphorylation of ERK1/2. Int J Mol Med 36: 733-738, 2015.

52. Yang L, Su T, Lv D, Xie F, Liu W, Cao J, Sheikh IA, Qin X, $\mathrm{Li} \mathrm{L}$ and Chen L: ERK1/2 mediates lung adenocarcinoma cell proliferation and autophagy induced by apelin-13. Acta Biochim Biophys Sin (Shanghai) 6: 100-111, 2014.

This work is licensed under a Creative Commons Attribution-NonCommercial-NoDerivatives 4.0 International (CC BY-NC-ND 4.0) License. 